\title{
O Zhuāngž̆ e as palavras-cálice: uma visão de linguagem pragmática radical na China do século IV aC
}

\section{Zhuāngž̌ and goblet words: a radical pragmatic view in China's $4^{\text {th }}$ century $B C$}

Cristiano Mahaut de Barros Barreto

Universidade Federal Fluminense, Niterói, Rio de Janeiro / Brasil cristianombb@gmail.com

Resumo: No presente artigo, analiso a visão de linguagem do clássico chinês taoísta Zhuāngž̌ 莊子 (c. século V-III a.C.), com foco no capítulo 27, onde seu autor sugere, por meio da tríade metalinguística das palavras convidadas, palavras repetidas e palavras-cálice, uma visão marcadamente singular na tradição chinesa, ainda pouco explorada pela sinologia e na história das ideias linguísticas (HIL). Em tradução comentada inédita para o português do início do capítulo 27 do Zhuāngzĭ, proponho que a leitura de suas linhas revele uma linguagem poderosa e libertária e, ao mesmo tempo, eivada pela sua própria propensão à imposição de categorias e ontologias. O Zhuāngž̌ sugere uma abordagem profundamente inovadora, com a qual traço aqui paralelos elucidativos e também inéditos, até onde tenho conhecimento, com a abordagem pragmática do conceito de linguagem como forma de vida de Wittgenstein. Apoiando-me na visão teórica historicista moderada de Auroux e no perspectivismo metalinguístico associado a Harris e Taylor, identifico afinidades que transcendem tempo e espaço e, ao mesmo tempo, recusamse a ceder ao reducionismo ou a hierarquias paralisantes. Ao longo do eixo de uma filosofia comparativa Leste/Oeste, sugiro que o termo final da tríade zhuangziana, palavras-cálice, represente o poder renovador e libertador da linguagem cujos traços entrevemos na linguagem ordinária 
de Wittgenstein. Finalmente, concluo com um convite para que se restaure a posição merecida do Zhuāngž̌ na HIL chinesa, ressaltando o papel fundamental do seu capítulo 27 nessa história.

Palavras-chave: Zhuāngž̆; Wittgenstein; metalinguagem; palavrascálice.

Abstract: In this article, I analyze the language view of the Chinese Taoist classic Zhuāngž̌ 莊子 (c. 5th-3rd century BC), focusing on Chapter 27, in which the author suggests, through the metalinguistic triad of invited words, repeated words and goblet words, a remarkably unique view within the Chinese tradition, still largely unexplored by sinologists and authors working on the History of Language Ideas (HLI). In a previously unpublished translation to the Portuguese of the beginning of Chapter 27 from the Zhuāngž̌, I propose that the text supports a powerful and libertarian language that at the same time is plagued by its own propensity to impose categories and ontologies. The

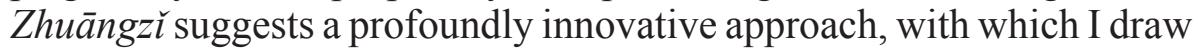
illuminating and not yet published - as far as I am aware - parallels with the pragmatic approach of Wittgenstein's language as a form of life. Relying on Auroux's theoretical moderate historicist vision and the metalinguistic perspectivism associated with Harris and Taylor, I identify affinities that transcend time and space and at the same time refuse to yield to reductionism or to paralyzing hierarchies. Along the axis of an East/West comparative philosophy, I suggest that the final term of the Zhuangzian triad, goblet words, represents the renovating and liberating power of a language in which we see signs of Wittgenstein's ordinary language. Finally, I conclude with an invitation to restore the welldeserved prominence of the Zhuāngzl̆ in the Chinese HLI, with particular attention to the key role of its Chapter 27.

Keywords: Zhuāngž̆; Wittgenstein; metalanguage; goblet words.

Recebido em 30 de outubro de 2017.

Aceito em 19 de dezembro de 2017. 


\section{Introdução}

忘年忘義，振於無竟，故寓諸無竟! wàng nián wàng yì, zhèn yú wú jìng, gù yù zhü wú jìng! Esqueça anos, esqueça distinções. Jogue-se no sem-fim, e assim sinta-se em casa ali!

(Zhuāngzǐ, cap. 2)

Beim Philosophieren muß man ins alte Chaos hinabsteigen und sich dort wohlfühlen.

Na filosofia é preciso descer até o caos primordial e lá se sentir à vontade.

(Wittgenstein, MS 136 51a: 3.1.1948) ${ }^{1}$

Subscrevendo o estudo da História das Ideias Linguísticas (HIL), ${ }^{2}$ compreendemos a história das línguas como continuamente marcada pelas pressões socioculturais dos povos da Terra e intimamente ligada às noções de cultura e identidade nacionais. Da mesma forma, também os pensares sobre a linguagem estão necessariamente situados histórica e culturalmente, em complexa inter-relação, o que torna a linguagem não um mero objeto passivo e isolado de estudo, mas, sim, o resultado de um multifacetado jogo de representações inseridas em seus contextos de produção.

Essa abordagem é ainda mais relevante para a história dos pensares sobre a linguagem na China clássica, onde as políticas linguísticas - em particular após a efêmera unificação do espaço cultural chinês sob a dinastia Qín 秦 (221-206 a.C.) - exerceram um profundo efeito sobre o uso linguístico no nascente império, sob a égide de uma meritocracia centralizadora e controladora. A despeito da brevidade dos Qín no trono imperial, foi profundo e durador o impacto de suas políticas linguísticas sobre os chineses, em particular por meio do início de um processo de completa reformulação e padronização da escrita chinesa. ${ }^{3}$

\footnotetext{
${ }^{1}$ Todas as traduções de citações no presente artigo são de minha responsabilidade.

${ }^{2}$ Associado a Auroux (1995, 1992 e 2000)

${ }^{3}$ Para uma abordagem geral sobre a escrita chinesa, inclusive sua história, ver Barros Barreto (2011) ou Alleton (2008).
} 
Em linhas gerais, na história do pensamento chinês tradicional, podemos afirmar que as reflexões linguísticas chinesas têm suas origens na efervescência cultural ocorrida na dinastia Zhou oriental (dōngzhōu 東周, 1030-221 a.C.), o longo, fértil e conturbado período histórico chinês que precedeu os Qín. Os textos escritos à época constituíram a base do cânone tradicional chinês e nortearam os pensares chineses em sua multimilenária história. Ainda que a filologia (xiăoxué 小學) e os estudos literários não tivessem ainda tomado um papel protagonista nesse período, já encontramos passagens que demonstram uma atenção especial sobre a linguagem, marcadamente sobre a relação entre os nomes e a realidade. No desenvolvimento subsequente das reflexões chinesas sobre a sua língua e, em particular, sobre sua escrita, seu curso tomou caminhos muito particulares, centrados na lexicologia/exegese de textos (xùngŭ 訓詁), na dialetologia (fāngyánxué 方言學) e no estudo dos caracteres chineses (zish $\bar{u}$ 字書), relegando a um papel secundário interesses como a gramática e a sintaxe. ${ }^{4}$ Vemos em autores seminais como Mòž 墨子 (c. 468-391 a.C.) e Xúnzǐ 荀子 (c. 312-230 a.C.) uma acentuada preocupação com a chamada questão da "retificação dos nomes" (zhèngmíng 正名), a análise e eventual ajuste na relação apropriada entre os caracteres chineses (os "nomes", ming 名) e seus denotata (as “coisas", 5 sh $i$ 實), necessária à compreensão "correta" entre as pessoas. As correntes antagonistas que depois foram convencionalmente chamadas de Moísta (mòjiā 墨家, escola [dos seguidores] de Mòzì) e Confucionista (rújiā 儒家, escola dos acadêmicos) formularam justificativas para os inúmeros pares nomes /coisas em consonância com seus próprios preceitos filosóficos sobre o que entendiam ser comportamentos corretos.

É no contexto desse debate que localizamos a importância da contribuição de um dos textos canônicos da tradição Taoísta e

\footnotetext{
${ }^{4}$ Para discussões mais detalhadas sobre a história do surgimento e desenvolvimento das reflexões chinesas na época clássica, veja-se Elman (1982), Lepschy (1994, cap. 1), Auroux (1995, cap. VI), Wang (2005, cap. 1), Bottéro (2008, 2011), Wang; Sun (2015, parte 1) e O’Neill (2016, cap. 10-15).

5 shí 實, que é muitas vezes traduzido como "coisas" ou "realidade", é um termo fortemente polissêmico cuja interpretação é alvo de extremadas discussões, particularmente quando traduzido por termos relacionados à metafísica ocidental. Owen (1992), em uma leitura particularmente feliz, entende-o como sólido, atual (as vezes em oposição à $x \bar{u}$ 虛, vazio), referindo-se à fixidez de uma forma definida, em sua realização concreta.
} 
chinesa, imensamente influente na história da China e na constituição de sua identidade cultural, o Zhuāngž̌ 莊子. O presente artigo se atém especificamente à contribuição do Zhuāngžr para a HIL na China tradicional durante o período formativo na era $Z h \bar{u} u$ oriental, focandose detalhadamente na leitura atenta do início do capítulo 27 do livro, ineditamente tratada na academia brasileira. ${ }^{6}$

A situação do Zhuāngzì na época nascente da reflexão linguística chinesa e na criação de todo um novo vocabulário chinês para lidar com as práticas linguísticas dá indícios da adequação de uma exploração mais minuciosa das práticas metalinguísticas chinesas, que se coalesceram a partir de usos inaugurais e seminais ao longo da história chinesa. Termos que usualmente traduzimos do chinês como escrita, dialeto, etimologia, palavra, tradução e mesmo linguagem tomaram usos muito diversos daqueles para os quais nos sugerem os discursos linguísticos ocidentais ou mesmo o que entendemos como o "senso comum" dessas palavras. São. portanto, instâncias propícias para o desenvolvimento de um trabalho comparativo na HIL, que objetiva dar uma contribuição na mesma linha que o ambicioso projeto de Sylvain Auroux (1995, 1992, 2000, 2004, 2009).

Ao pensamento inspirador e influente de Auroux, adiciono interlocuções com autores como Taylor (1997, 2000, 2003) e Harris (1981, 1988, 2001), que, em suas abordagens radicalmente antidogmáticas e historicistas, criticaram o que Harris batizou de "Mito da Linguagem", ou seja, que a linguagem seria um sistema fixo de códigos e mero instrumento passivo de representação. Para Taylor, os usos leigos da linguagem nos levam à constituição de um senso comum quando frequentemente a reificamos. Esse senso comum influencia diretamente os discursos acadêmicos, a despeito de suas pretensões cientificistas e neutralistas. Finalmente, beneficio-me particularmente do diálogo profícuo com a ideia de Linguagem como Forma de Vida, de Wittgenstein (1998, 2009)

\footnotetext{
${ }^{6}$ Há hoje muito poucas alternativas de leitura do Zhuāngzǐ em português. Os livros disponíveis (nas referências) são traduções indiretas via língua inglesa, limitados aos "capítulos internos" (os sete primeiros capítulos do livro) ou a uma seleção de passagens/ anedotas do livro. Para o presente trabalho de análise e tradução, apoiei-me no texto original e nas traduções em inglês e em chinês (nas referências). Para bem trabalhadas introduções em português ao Zhuāngzǐ e ao pensamento filosófico chinês clássico, veja-se Lai (2009, p. 169-200) e Souza (2016).
} 
- que lemos nos textos de sua fase mais madura, em especial seu seminal Investigações Filosóficas, e também nas leituras de Cavell (1979) e Glock (1996) - em que a linguagem não pode ser reduzida a qualquer teoria universalizante ou tomada como um objeto hermeticamente isolado de estudo. Em particular, ressalto a importância da ideia da linguagem ordinária, a linguagem comum que Wittgenstein frequentemente lauda em seus textos (WITTGENSTEIN, 2009, §98, 105, 116, 243; CAVELL, 1979 , p. 180) em oposição àquela do discurso técnico, calculado e com pretensões de certeza e de não ambiguidade. ${ }^{7}$

O pensamento desses autores articula-se com uma abordagem que toma os textos chineses como discursos, carregados de uma ideologia, não somente retratos de um contexto sócio-histórico de produção, mas também agentes ativos na construção de um pensamento sobre a linguagem e sobre o mundo.

Considero o Zhuāngž̌ um trabalho fundamental para a HIL na China clássica. Trata-se de um texto particularmente rico em metalinguagem e em expressões inaugurais da língua chinesa, fonte de usos inovadores de caracteres chineses que progressivamente seriam incorporados de diversas maneiras ao vocabulário corrente de sua língua. Um termo particularmente caro à sua visão de linguagem que podemos entrever no texto é zhīyán 厄言, introduzido no capítulo 27. Seu uso no âmbito da tríade yùyán 寓言, chóngyán 重言 e zhìyán 后言 é o objeto central da análise deste artigo e se mostrará fundamental, como argumentarei adiante, às representações de linguagem de todo o Zhuāngzĭ. Mostrarei que, no capítulo 27, encontramos explicitada uma visão de linguagem radicalmente inovadora, poucas vezes abordada no contexto do Zhuāngž̆ e ainda, até onde tenho conhecimento, não examinada à contraluz das ideias teóricas apoiadas nos textos de Auroux, Taylor, Harris e Wittgenstein. Assim, ao longo do presente artigo, espero poder transmitir ao leitor uma afinidade que extrapola os séculos e a distância geográfica entre o discurso profundamente antidogmático sobre a linguagem lida

\footnotetext{
${ }^{7}$ A caracterização do discurso wittgensteiniano como aquele que emprega uma linguagem "comum" é controversa, uma vez que seus textos são povoados por um vocabulário que pode ser facilmente considerado extremamente técnico. O uso de um discurso técnico para louvar a linguagem ordinária pode entretanto ser reconhecido como típico das contradições inerentes da linguagem e do texto do filósofo. Para uma discussão sobre essa questão, ver, por exemplo, Barros Barreto (2015, p. 24-53).
} 
no Zhuāngž̌ e naqueles textos de Wittgenstein e Harris. Seus paralelos, em vez de indicar uma vocação universalista que reunisse esses autores sob a égide de conceitos e doutrinas postulados além de suas diferenças culturais e históricas, muito ao contrário, dá-nos mostras de pensadores que, mesmo fundados sobre tradições radicalmente diversas, ainda assim nos propõem o olhar vigorosamente libertador de uma linguagem soberana e poderosa. ${ }^{8}$

\section{Zhuāngž̆}

Pouco se sabe sobre o personagem histórico homônimo e autor do Zhuāngž̆, um dos mais importantes e conhecidos pensadores da época de ouro da filosofia chinesa. O que conhecemos, lê-se do capítulo 63 do Shǐji 史記 (o "Livro da História"), em que seu nome pessoal aparece como Zhuāng Zhōu 莊周, nativo de Sòng 宋 no sul da China, onde teria sido um pequeno oficial. ${ }^{9}$

Zhuāngzì tornou-se conhecido por sua loquacidade e habilidade como um gentleman, a ponto do rei Wèi 魏de Chǔ 楚 (r. 339-329) tentar cooptá-lo oferecendo-lhe o posto de primeiro ministro. Ele foi provavelmente contemporâneo dos filósofos Mencius (Mèngž 孟子, c. 372/85-303/289 a.C.) e Hui Shī 惠施 (380-305 a.C.) e do poeta Qū Yuán 屈原 (c. 340-278 a.C.) no século IV a.C. Vendo a anexação progressiva de Sòng pelos estados vizinhos $Q i$ 齊, Wèi 衛 e Chǔ 楚, Zhuāngzĭ foi naturalmente marcado por uma visão bastante pessimista sobre o resultado de articulações de cunho político.

Kohn (2014, p. 1) descreve-o como uma pessoa com fortaleza de caráter, ardoroso, com uma audácia intelectual, cativante e extravagante, nunca tendencioso, jamais se exaltando. Pobre e simples em vestimentas e gostos, era alguém que não confiava em regras oficiais, em categorias padronizadas ou opostos estabelecidos.

\footnotetext{
${ }^{8}$ Devido ao escopo do presente artigo e suas limitações de espaço, não será dado aqui o tratamento mínimo adequado a autores do porte de Auroux, Harris ou Wittgenstein. Como referência, além dos textos dos próprios autores, indico também meu trabalho (BARROS BARRETO, 2015) em que este arcabouço teórico é desenvolvido em contraste com o pensamento linguístico do Lăož̆ ${ }^{9}$ Referências sobre a vida de Zhuāngž̆, veja-se Graham (1989, p. 3-4), Mair (1994, p. xxxi-xxxv), Ziporyn (2009, p. vii-viii), Watson (2013, p. 7-8), Wang (2014, introdução), Kohn (2014, p. 1-4) e Souza (2016, p. 14-16).
} 
Sua biografia no Shǐji menciona que seus textos perfaziam cerca de cem mil caracteres. Como outros pensadores de seu tempo, não foi sua prioridade organizar suas ideias sob a forma de textos, tendo talvez escrito versos, estórias e alguns aforismos. Nada que se assemelhasse à estrutura de um livro parece ter aparecido antes dos sécs. III-II a.C. A primeira versão que conhecemos do Zhuāngž̌ foi um texto de cinquenta e dois rolos (piān 篇) editado por Liú Xiàng 劉向 (79-8 a.C.). ${ }^{10}$ Outras versões (mais curtas) circulariam nos próximos séculos até a padronização final do texto, que consiste em trinta e três capítulos. Essa versão canônica foi editada por Guō Xiàng 郭象 (†312 d.C.) $)^{11}$ e considerada pelos estudiosos hoje como a "mais importante e o texto base para os pensadores chineses posteriores" (KOHN, 2014, p. 93).

O texto, conforme estabelecido por Guō Xiàng, consiste de três seções: nèi piān 內篇 (capítulos internos), capítulos 1 a 7; wái piān 外篇 (capitulos externos), capítulos 8 a 22; e zá piān 雜篇 (capítulos diversos), capítulos 23 a 33. Até a dinastia Sòng 宋 (960-1279), os estudiosos chineses consideravam que todo o texto do Zhuāngž̆, homônimo de seu autor putativo - o que era comum na tradição chinesa -, teria sido escrito por uma única pessoa, o que hoje se sabe não poder ter acontecido (KOHN, 2014, p. 6). ${ }^{12}$ Por outro lado, é em geral consenso entre a maioria dos estudiosos que os capítulos internos formam um texto mais coeso e estilisticamente mais rico e original a ponto de serem aqueles mais proximamente associados ao autor que deu nome ao livro (WATSON, 2013, p. 13). ${ }^{13}$

\footnotetext{
${ }^{10}$ Alguns autores, como Mair (1994 p. xxxvii) afirmam que o Zhuāngž̌ foi compilado um pouco antes, por Liú An 劉安 (†122 aC), o príncipe de Huáinán 淮南, na dinastia Hàn 漢.

${ }^{11}$ Para maiores detalhes sobre a história textual do Zhuāngž̌, veja-se Knechtes; Chang (2014, p. 2314-2323), Kohn (2014, cap. 1 e cap. 9) e Liu (2015, cap. 6).

${ }^{12}$ Há diversos anacronismos ao longo do livro, além de mudanças drásticas no estilo do texto que apoiam a tese de que ele teria sido escrito por diversos autores. Até mesmo a autoria única dos capítulos internos é disputada. Veja-se, por exemplo, discussão em Mair (1994, p. xxxviii) ou em Cook (2003, p. 11).

${ }^{13}$ A despeito da importância dos "capítulos internos", não há evidências claras de que eles foram escritos antes do restante do texto. Para Kohn (2014, p. 7), os "capítulos internos" foram obra de múltiplos autores como um extrato posterior do texto, representando uma coleção de materiais que circulavam à época Hàn sob o nome de Zhuāngzǐ. Autores como Graham (1981) associam os capítulos internos ao nome do autor histórico Zhuāngzǐ. Allinson (1989, p. 6-7) e Wang (2014, p. 161) veem os capítulos internos como aqueles mais "genuínos" na representação do pensamento de Zhuāngzĭ.
} 
O texto é considerado por muitos um dos mais belos e literariamente sofisticados da China antiga (MAIR, 1994, p. xlv; YU et al., 2000, p. 71). Ele é repleto de anedotas, em que uma multiplicidade de personagens mundanos aparece junto à copiosa seleção de deuses, heróis míticos, árvores falantes, pássaros, insetos etc. (WATSON, 2013, p. Xxviii).

Junto com o Lăozl̆ 老子 e o Lièzľ 列子, o Zhuāngž̌ compôs a tríade dos textos fundadores do Taoísmo filosófico. Produzido e editado antes do desenvolvimento da corrente institucional do Taoísmo, ${ }^{14}$ o texto serviu ao longo do tempo aos mais diversos propósitos. Constituiu um manual para a longevidade e um catálogo de práticas esotéricas, foi também empregado como base de um sistema filosófico associado ao cerne do taoísmo nascente à época dos Estados Guerreiros (zhàngguó shídài 战国时代, 481-221 a.C., no período Zhōu) e até mesmo como apoio a outros sistemas filosóficos, como o Budista e o Neo-Confucionista (ZIPORYN, 2009, p. xi). Não devemos esquecer, sobretudo, que se trata de um texto proeminentemente literário, que emprega com maestria as palavras de uma maneira engajante e, muitas vezes, desconcertante.

De uma forma geral, podemos entender os livros dos sábios chineses como manuais de conduta, de um agir em conformidade com algum dào 道, o "caminho" particular que orienta e leva às práticas corretas receitadas segundo os ensinamentos de cada uma das diferentes escolas do pensamento chinês. O Taoísmo, dàojiā 道家, é uma linha de pensamento cujo nome chinês significa exatamente "escola do dào," o que ressalta o papel fundamental desse conceito em sua doutrina. É possível argumentar, todavia, que o Taoísmo, de modo geral, e o Zhuāngž̆, em particular, não propõe apenas mais uma linha de comportamento ("mais um" dào), mas nos oferece argumentos de ordem superior sobre o que poderíamos entender como "dào" - o texto é, portanto, um "dào sobre dào" (HANSEN, 1992, p. 202-209; ZIPORYN, 2009b) - e nos orientaria a seguir esse "meta-dào" que justamente se recusa a orientar ou a prescrever (ZIPORYN, 2009, p. xiii-xiv)! Como veremos a seguir, o princípio de

\footnotetext{
${ }^{14}$ Muitos pensadores consideram que oTaoísmo pode, heuristicamente, ser dividido em uma tradição filosófica (dàojiā 道家) e outra religiosa (dàojiào 道教). Suas versões institucionalizadas surgiram posteriormente e essa fronteira é questionada por alguns autores. Para outras referências, ver Kohn; Roth (2002), Kohn (2014, cap. 11) e Liu (2015, parte III e IV, e cap. 20).
} 
um dào não coercitivo torna-se natural e inevitável a partir do momento em que aceitamos a premissa taoísta da liberdade total em um mundo em inesgotável e ininterrupto processo de mudanças.

Seu aspecto meta-argumentativo e não autoritário (portanto, antidogmático) é um fator que torna o Zhuāngž̌ particularmente complexo (e por vezes, um tanto convoluto e de difícil compreensão), que parece querer impor-se a uma leitura em seus próprios termos, em vez de ceder a uma decodificação. Isso, entretanto, torna o uso da linguagem no texto especialmente relevante e, por meio dela, oferece-nos o vislumbre sobre uma filosofia de linguagem absolutamente original e revolucionária.

\section{A filosofia do Zhuāngž̌ e a linguagem}

Chuang Tzu não se preocupa com palavras, nem com fórmulas sobre a realidade, mas com a aquisição existencial direta da realidade como tal. Esta aquisição é necessariamente obscura e não se presta a uma análise abstrata. (MERTON, 2003, p. 16)

A questão da linguagem no Zhuāngž̌ surge frequentemente ao longo de seu texto, de uma maneira sutil e indireta, e acaba passando despercebida por autores para os quais essa não é uma preocupação central. A citação em epígrafe é o paroxismo do ponto de vista desses autores. Na seleção de passagens do texto traduzidas por Merton - um monge católico que viu no Zhuāngž̌ uma rica fonte de espiritualidade não há qualquer trecho retirado dos capítulos 1 ou 2, ou seja, aqueles que introduzem seu sistema filosófico. Claramente, a questão da linguagem e a filosofia do Zhuāngzǐ não fizeram parte do foco da atenção de Merton, que assim os descartou como estranhos - ou "obscuros" - ao texto.

Entretanto, hoje a maior parte dos estudiosos que se dedicam ao estudo do Zhuāngzǐ veem nele uma filosofia indissociável de uma visão marcadamente original sobre a linguagem dentro da tradição chinesa. Alguns exemplos são ilustrativos. Segundo Billeter (1990, p. 162), a perícia no manejo da palavra no Zhuāngž̀ não apenas ilustra seus pontos de vista, mas seria prova conclusiva da justiça de sua posição filosófica, em que a linguagem chama para si um papel absolutamente protagonista. Para Stephen West (YU et al., 2000, p. 72) o Zhuāngž̌ é o texto que, 
melhor do que qualquer outro no cânone chinês, mostra como a linguagem da classificação pode ser desestabilizada por aquela da experiência. $\mathrm{O}$ autor argumenta que a "performance virtuosa" do texto do Zhuāngzì nos dá testemunho de um controle e precisão no uso de seus termos e assim nos guia no aparentemente confuso labirinto da realidade. Outros autores, como Willard Peterson (YU et al., 2000, p. 104), veem a capacidade do texto de subverter-se e arremeter-se em seguidas contradições como ao mesmo tempo uma fonte de frustrações e um claro sinal de que o Zhuāngž̆ não busca oferecer significados ou respostas, mas, sim, provocar uma leitura engajada e coparticipativa. Já Kjellberg; Ivanhoe (1996) editaram um livro inteiramente dedicado às estratégias linguísticas no Zhuāngž̆, atendo-se a questões a respeito de seu relativismo e ceticismo - embora tenham praticamente ignorado o capítulo 27 , dedicando-se aos capítulos internos. A linguagem, portanto, deve justificadamente ser reconhecida como um dos pontos de partida para entendermos a filosofia do Zhuāngž̆ e sua crítica às diferentes escolas do pensamento chinês da época Zhōu.

Ambos os pensamentos afeitos às escolas ditas Confucionista e Moísta na China clássica fundaram-se sobre a escolha de uma premissa básica particular para sustentar a harmonia entre o Ser Humano (rén 人) e a Natureza (zìrán 自然, ou o "Reino Celestial”, tiān 天): seja o comportamento ritual/virtuoso (rényì 仁義) e o inatismo de Mencius (um dos mais próximos seguidores de Confúcio), seja o amor universal (jiān'ài 兼愛) e o utilitarismo (li 利) de $M \grave{z} z \grave{i} .{ }^{15}$ A linguagem, segundo esses pensadores, deveria ser empregada de forma a se sujeitar a essas premissas e, se necessário, deveria ser forçosamente regulada para tal (representada pelo termo chinês, zhèngmíng 正名a chamada "doutrina da retificação dos nomes"16). Na visão inclusiva e pluralista de Zhuāngž̆, o próprio ajuste ou tentativas de uma sistematização da linguagem constituiriam agentes provocadores de distúrbios nessa harmonia, uma vez que eles representariam ações humanas em choque contra o fluir da “natureza” (o “ser assim”, zíràn 自然, tradução um pouco mais literal do termo chinês associado à natureza).

${ }^{15}$ Para saber mais sobre a filosofia Confucionista, de Mencius e de Mòž̆,ver Fung (1934, cap. 4 e 5), Chan (1963, cap. 2-6 e 9), Cua (2003, verbetes), Lin (2006, cap. 2-5), Lai (2009, cap. 2, 3 e 4) e Souza (2016, cap. 1.5).

${ }_{16}$ Sobre zhèngmíng, expressão fundamental no pensamento linguístico chinês, ver Hansen (1982, p. 319-333), Bao (1990, p. 196-200, p. 205-207), Cua (2003, p. 870-871), Wang (2005, cap. 1) e O’Neill (2016, cap. 10). 
Em linhas muito gerais, já no primeiro capítulo (xiāoyáoyóu 逍遙遊, Vagar descontraído e desimpedido) o Zhuāngž̀ inicia a exposição de um de seus objetivos mais fundamentais: a liberdade totalmente livre de amarras (WATSON, 2013, p. ix). É a premissa central taoísta ${ }^{17}$ da mudança e da completa inconstância do mundo (zàohuà 造化, fazer mudança ou, como um substantivo mais afeito ao pensamento ocidental, Princípio da Mudança) que nos possibilita a liberdade absoluta desde que aceita em sua forma mais radical, ou seja, naquela em que as ações não atuem como constrangimento ou obstrução ao fluxo natural de transformação. É por esse ângulo que sugiro pensarmos o notório conceito taoísta de “agir sem ação" (wúwéizhīwéi 無為之為), não como uma mera não ação ou uma atitude completamente passiva, mas, sim, o direcionamento da ação da forma mais não intrusiva possível, sem esforços, atritos ou resistências. Uma fundamental consequência direta da total imanência (no sentido de não permanência) e mudança é o desmantelamento de hierarquias fixas e artificiais e a aceitação da igualdade entre todas as coisas, como uma propensão natural que tudo afeta e por tudo é afetada. É importante, todavia, não confundir o espírito igualitário do texto com um ímpeto uniformizador, movimento que artificialmente impõe preconceitos e procura obliterar diferenças, portanto em direção oposta ao que nos sugere o Zhuāngzĭ.

A proposta de liberdade radical introduzida no primeiro capítulo dá seguimento à discussão no capítulo seguinte em sua ordenação canônica (qíwùlùn 齊物論, Discursando sobre a igualdade das coisas) sobre a maneira como se insere a linguagem nesse contexto de mudança. Esse capítulo é o que apresenta o maior número de referências explícitas a problemática da linguagem e se tornou um dos mais estudados e analisados do Zhuāngzĭ. ${ }^{18}$ Em consonância com seu ímpeto iconoclasta, o texto prega a não aceitação de novos dogmas, advertindo-nos, ao

\footnotetext{
${ }^{17}$ Esta premissa é profundamente afeita ao pensamento Budista, que penetrou na China vindo da Índia após o séc. I d.C. e que assim deu início a um processo de sincretismo absolutamente notável com o Taoísmo.

${ }^{18}$ Para o um estudo em português sobre o segundo capítulo do Zhuāngzľ e uma nova tradução, veja-se Souza (2016). Ver também Graham (1969) para um estudo clássico sobre o capítulo.
} 
contrário, do perigo do efeito dogmatizante da linguagem. ${ }^{19}$ É diante desse cenário que estudiosos se debruçam sobre a questão do ceticismo e sobre o relativismo no texto do Zhuāngzĭ, em particular no capítulo $2 .^{20}$

Uma das respostas oferecidas por alguns acadêmicos para a falta de constância da linguagem se apoia na proposta de alguma realidade extralinguística como alternativa ao quietismo frequentemente associado ao Taoísmo (particularmente ao $L a ̆ o z \iota^{21}$ ). Essa leitura vemos refletida na citação a seguir:

A realidade em última instância vai além da linguagem; a linguagem em última instância não tem palavras e é silenciosa - uma característica expressada na reivindicação taoísta de ser o "ensinamento com nenhuma palavra e o cultivo do 'jejum linguístico"”. (KOHN, 2006, p. 169)

Proponho, todavia, que a fluência do Zhuāngž̌ e sua insistente discussão sobre a linguagem afaste a opção quietista e privilegie uma linguagem que seja mais poderosa e abrangente. No capítulo 2 do Zhuāngž̆, encontramos a famosa passagem que nos diz que a linguagem não é "apenas vento," que ela tem "algo para nos dizer" e, dessa forma, aceitar uma linguagem "sem palavras" parece não indicar necessariamente que devemos nos calar (ALLINSON, 1989, cap. 1). Adicionalmente, o discurso de Zhuāngzǐ é, como podemos depreender de diversas passagens, ${ }^{22}$ aquele que oferece sugestões para uma conduta moral ao mesmo tempo que critica o discurso vazio de Confucionistas e Moístas (CUA, 2003, p. 916), o que não seria possível caso fosse estritamente cético ou relativista. Ao partir da liberdade sem amarras como o modelo de vida mais condizente com sua premissa inicial de transformação

\footnotetext{
${ }_{19}$ Advertência semelhante encontramos em Taylor sobre a normatividade do uso linguístico (TAYLOR, 1997, p. 11 e cap. 8) ou em Wittgenstein sobre palavras descontextualizadas (WITTGENSTEIN, 2009, §38, §116).

${ }^{20}$ Para discussões sobre o relativismo e o ceticismo, ver, por exemplo, Allinson (1989, cap. 8), Kjellberg; Ivanhoe (1996) e Cook (2003, cap. 5 e p. 165-172).

${ }^{21}$ Sobre a visão de linguagem associada ao Lăož̀, ver Barros Barreto (2015).

22 Ver, por exemplo, o capítulo 7, "Próprio para Imperadores e Reis" (yīng dì wáng 應帝王) e o capítulo 19, “Dominando a Vida” (dá shēng 達生).
} 
incessante, a filosofia do Zhuāngž̌ seria visivelmente autocontraditória se postulasse alguma "realidade" fixa e eterna, "além da linguagem." 23

Essa interpretação parece claramente justificada pelo debate continuado ao longo do livro entre Zhuāngž̌, o autor, e seu velho amigo e rival, Huì Shì, sem dúvida uma de suas maiores influências (ZIPORYN, 2009, p. xv-xvi; WANG, 2014, p. 7-9). Hui Shī foi o pensador mais representativo da chamada Escola dos Nomes (míngjiā 名家), a única "escola" chinesa de pensamento - embora os autores a ela identificados nunca tenham formado qualquer grupo ou formulado uma doutrina coesa - explicitamente centrada sobre as questões linguísticas. ${ }^{24}$ Resumidamente, seus autores sugeriram uma série de paradoxos com o intuito de evidenciar as inconsistências da linguagem na relação com as instâncias (ou realizações) de mundo (shi 實), adotando foco e método que nos remete aos sofistas da Grécia antiga. Partindo da tese da inconstância dos nomes e da impossibilidade de uma relação biunívoca e estável entre nomes e coisas, lemos nos trechos identificados a esses

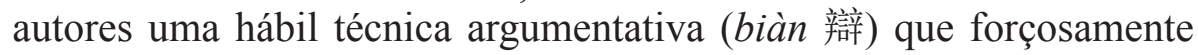
dirige o leitor a conclusões que se chocam com a realidade observável. A crítica a seus pensadores justamente se apoia na constatação de que o relativismo extremo da Escola dos Nomes é estéril e gera somente falácias

${ }^{23}$ Pressupor que Zhuāngzĭ faça referência a essa realidade última seria assumir uma epistemologia mística e esotérica em aparente discordância com o texto, já que em nenhum momento o autor parece afirmar deter um conhecimento exclusivo e interdito aos outros. Todavia a questão do misticismo no Zhuāngž̌ permanece sem um consenso e matéria de debate entre os estudiosos (para uma abordagem, veja-se, por exemplo, Cook, 2003, cap. 1). Em minha leitura - em concordância com o pensamento de Taylor (1997) e Wittgenstein (2009) - boa parte dessa discussão emerge da aplicação de um termo ocidental, "misticismo", com todas as suas implicações e bagagem histórica e cultural, na caracterização de um livro produzido em um contexto histórico e sociocultural muito diverso.

${ }^{24}$ Para Chan (1963, p. 232) quase todas as escolas do pensamento chinês tiveram interesse na relação entre nome e atualidade (míng 名 e shi 實), seja por sua relevância moral/ social (Confúcio), impacto "metafísico" (Taoísmo) ou controle político (Legalismo). Todavia, nenhuma estava especialmente voltada para sua coerência interna ou para o debate sobre a natureza dos nomes, como foi o caso da Escola dos Nomes. Para mais detalhes sobre a Escola dos Nomes, ver Chan (1963, cap. 10), Hansen (1992, cap. 7), Cua (2003, p. 491-8) e Lai (2009, p. 135-168). Especificamente sobre a relação entre Huì Shī e Zhuāngzǐ, ver Ames; Nakajima (2015, p. 7-10). 
negativas, uma inevitável conclusão decorrente da arbitrariedade total de todos os nomes (GRAHAM, 1969, p. 141). Chad Hansen (CUA, 2003, p. 912) defende a hipótese de que Zhuāngzǐ compreendia essa posição e a recusava veementemente, o que se deixa transparecer nas acaloradas discussões entre si e seu amigo e rival, Hui $S h \bar{r} .{ }^{25}$ Nesse embate, identificamos as fontes da complexidade da visão de Zhuāngž̌ sobre a linguagem, sustentada em equilíbrio precário, embora necessário: se por um lado ele vê-se obrigado a aceitar a liberdade e a convencionalidade da linguagem, por outro, reconhece os perigos de uma linguagem obstinada em se fixar de forma arbitrária às coisas nomeadas, assim obscurecendo o processo de infindável mudança preconizada pelo Taoísmo.

Partindo dessa questão central, embora os textos do Zhuāngž̆ sejam frequentemente reconhecidos como testemunho da reação à disputa entre Confucionistas e Moístas, cabe considerá-los também como um libelo contra o "ceticismo vazio" e o relativismo extremo do biàn da Escola dos Nomes, apesar de terem com estes sutis afinidades. O Zhuāngž̆, ao mesmo tempo que critica abertamente a argumentação infértil de Hui Shī, emprega a mesma maestria linguística na defesa de suas posições e na denúncia da inocuidade e da posição indefensável de Confucionistas e Moístas. Como nos explica Cua (2003, p. 913), o Zhuāngzĭ, quando nos mostra que os argumentos pragmáticos sempre são relativos a algum tipo de valor implícito, não nos obriga a abandonar o pragmatismo, mas apenas a atentar para o valor e o limite de suas conclusões.

Devemos ainda considerar que o Zhuāngž̌ está consciente de que seu conselho (moral) advém de uma perspectiva própria, normalmente identificada com o termo míng 明, traduzido como iluminação, discriminação ou perspectiva das perspectivas (CUA, 2003, p. 916). Entretanto, pelo que até aqui discutimos, é patente que qualquer "conclusão" a que cheguemos precisa ser necessariamente atenuada e nuançada. Kjellberg (1996, p. 127, cap. 6) discute essa dificuldade em conciliar o ceticismo do texto com a reivindicação do conhecimento privilegiado do Zhuāngzǐ sobre a Natureza em suas várias demonstrações de perfeição humana (como no já citado capítulo 19, Dominando a

${ }^{25}$ Huì Shī aparece no Zhuāngzǐ nos capítulos 1, 2, 3, 5, 17, 18, 24, 25, 26, 27 e 33, sendo este último a principal fonte de informações nos textos clássicos chineses sobre o pensador. 
$V i d a)$. Esse autor propõe, então, dois tipos de conhecimento no texto: um conhecimento prático, voltado à destreza e à perícia, e um conhecimento teórico, ou dos fatos; o primeiro é dinâmico e improvisante, oferece saídas e dá acesso ao mundo natural; já o segundo é rígido, sem saída, e limitado em suas próprias regras arbitrárias. Nessa leitura, o ceticismo do Zhuāngzǐ seria, portanto, um ceticismo sobre o conhecimento "teórico."

O conhecimento teórico, aquele que produz teses e afirmações dogmáticas, estaria assim fadado ao problema do engessamento da linguagem, distorcendo-a para satisfazer os propósitos daquele que argumenta, dividindo arbitrariamente o mundo entre “isso's" (shi 是) e “aquilo's" ( $b \check{l}$ 彼) diferentes (produtos de pontos de vista diferentes). Ao aventar a possibilidade de uma via alternativa, aquela do conhecimento prático, o Zhuāngž̌ recusa o relativismo inócuo resultante da simples negação de qualquer forma de conhecimento. A prática sugerida pelo texto é aquela que não parte de alternativas preconcebidas, ou mesmo distingue alternativas diferentes, mas vê cada opção como uma que, a cada momento, se oferece de maneira mais "maleável" e, dessa forma, não escolhe conscientemente, mas "deixa-se levar" (GRAHAM, 1969, p. 144). Diante dos perigos de uma linguagem que impõe classificações e dá ilusões de aparente estabilidade, o Zhuāngž̌ nos propõe uma linguagem alternativa, ela mesma uma contradição de termos - não há "linguagem alternativa" que não seja linguagem, e, portanto, em última instância, não há alternativa à linguagem - mas cujos vislumbres antevemos em sua perícia estilística:

Zhuangzi procura desenvolver um novo estilo de linguagem filosófica que lhe permita discursar sobre todos os enunciados como iguais [...] Ele confirma a expressão verbal como a arte do possível (YU et al., 2000, p. 97)

\footnotetext{
${ }^{26}$ Fica difícil, na perspectiva de Taylor, Auroux e outros já citados aqui, a aplicação do termo "ceticismo", com toda sua carga de usos e contextos ocidentais, a um texto inserido na tradição antiga chinesa sem que se caia em uma mera discussão de nomenclatura ("seria o Zhuāngž̌ é ceticista no sentido da sképsis grega?"). O propósito do uso do termo "ceticismo" aqui é fornecer um guia que ajude o leitor a criar aproximações entre estratégias e formas de pensamento tão diferenciadas como as do Zhuāngzǐ e a tradição ocidental de origem grega.
} 
Ao procurar abordar uma linguagem que seguidamente se desvencilha de descrições e mostra-se avessa a categorizações, chegamos ao capítulo 27 - foco do presente artigo - como aquele de particular importância para compreendermos a visão de linguagem do Zhuāngž̌. Sua escolha deve-se a duas razões principais. Em primeiro lugar, uma vez que o capítulo 27 não faz parte dos "capítulos interiores", muitos daqueles que analisam o texto não dão a devida atenção ou não o consideram como representante do pensamento "legítimo" de Zhuāngž̌. Todavia, o texto sempre foi considerado como um todo pela tradição exegética chinesa e, assim, independentemente de questões autorais, não devemos menosprezar sua influência sobre a tradição chinesa e sua articulação com o restante do livro. Em segundo lugar, seu contraste com os outros capítulos do livro, no que concerne à linguagem, torna-o ainda mais relevante, a ponto de Wang (2014, p. 21) chamá-lo de "principal capítulo que descreve a linguagem do Zhuāngz" ". A liberdade suprema de uma linguagem viva e em eterna mutação, não só explicitamente defendida no longo do capítulo 2, mas também presente em todo a pujante matéria linguística do Zhuāngž̆, parece ser contradita em um impulso classificatório no capítulo 27, como veremos a seguir. Sugiro, entretanto, que, muito ao contrário de desmentir o restante do livro, o capítulo 27 termine por reforçar e explicitar suas premissas, ressaltando as características da linguagem focada através das lentes do Zhuāngž̆, em suas capacidades e limites, o que a faz tão poderosa e ao mesmo tempo, tão perigosa.

\section{0 capítulo 27 e as palavras-cálice}

Como já observado anteriormente, o capítulo 27 do Zhuāngž̆, embora não pertença ao conjunto dos sete capítulos internos, é fundamental para a compreensão da visão de linguagem subjacente ao livro.

Embora autores como Watson (2013, p. xix) argumentem que os capítulos miscelâneos (vinte e três ao trinta e três) poderiam ter sido escritos até seis ou sete séculos após a vida de Zhuāngž̌ e teriam pouco impacto sobre o cerne de sua filosofia, essa não é uma posição consensual na discussão acadêmica sobre o texto (COOK, 2003, p. 11). Kohn (2006, p. 8), por exemplo, escreve que, na discussão sobre a cronologia das partes do texto, é perfeitamente razoável que o capítulo 27 pudesse ter sido um prefácio de sua edição mais antiga (com o último capítulo, o 33, servindo de posfácio). Como já foi comentado, independentemente dessas 
questões autorais e textuais, é inegável haver uma relação íntima entre o capítulo 27 e os capítulos internos, em especial entre ele e o capítulo 2 , em seu tratamento sobre a linguagem.

O título do capítulo 27 é yùyán 寓言, que repete os dois primeiros caracteres do início do texto e já é, por si só, um dos três termos metalinguísticos em destaque. O termo yùyán é hoje dicionarizado como fábula, alegoria, parábola (fable, allegory, parable) (QIU, 2005, p. 221) e já era utilizado em chinês clássico para se referir a um estilo literário marcado por anedotas e parábolas (pequenas histórias), com um intuito muitas vezes satírico e com a presença comum de animais antropomorfizados, uso de analogias e referências metafóricas, frequentemente discorrendo sobre situações cotidianas com o objetivo de levar o leitor a algum tipo de reflexão ou moral. A diversidade de traduções escolhidas para o título do capítulo dá sinais da complexidade na adaptação da expressão yùyán em línguas ocidentais: "On Metaphors" (Sobre Metáforas) (BALFOUR, 1881) "Language” (Linguagem) (GILES, 1889), "Metaphorical Words" (Palavras metafóricas) (LEGGE, 1891; MAIR, 1994), "Verbes et Mots" (Verbos e Palavras) (WIEGER, 1913), "Words lodged elsewhere" (Palavras acomodadas em outro lugar) (ZIPORYN, 2009) e "Imputed Words" (Palavras imputadas) (WATSON, 2013). ${ }^{27}$

As traduções clássicas de Giles e Wieger explicitam o objeto principal do capítulo, nomeadamente, a linguagem. As outras estão relacionadas às diferentes interpretações dos tradutores sobre a expressão yùyán, cuja discussão veremos a seguir.

${ }^{27}$ A tradução de Balfour, "The Divine Classic of Nanhua, Being the Works of Chuang Tsze, Taoist Philosopher" (1881), é a mais antiga extante do Zhuāngž̌ (COOK, 2003, p. 263), e os livros de Giles, "Chuang Tzu: Mystic, Moralist, and Social Reformer" (1889) e de Legge, "The Writings of Kwang-Tze" (1891), fizeram parte do extenso trabalho de tradução dos dois autores do cânone chinês (KNECHTES; CHANG, 2014, v. III, p. 2314-2323). Segundo Cook (2003, p. 286), até aquela data, além das traduções de Balfour, Giles e Legge no séc. XIX, as únicas outras traduções completas para o inglês seriam as de Watson (2013, originalmente escrita em 1968), Mair (1994) e Palmer (1996). A tradução para o francês de Wieger, "Nan-hoa-tchenn-king: l'oeuvre de Tschoang-tzeu" é uma das mais antigas naquele idioma e, apesar de suas limitações, ainda hoje é muito utilizada na França (BILLETER, 1990, p. 170). Para uma discussão crítica das traduções do Zhuāngzĭ, embora já desatualizada, veja-se também Mair (1983, p. 158-161). Para uma seleção mais recente de referências sobre o Zhuāngzĭ, veja-se Cook (2003, p. 291-295). Para uma breve discussão dos principais comentários chineses, veja-se Ziporyn (2009, p. 221-227). 
Embora se trate de um capítulo relativamente curto do livro, por uma questão de espaço e escopo, restrinjo-me, no presente artigo, a apresentar somente uma sugestão de tradução comentada de seu início, ou seja, das passagens em que o texto descreve explicitamente o que propõe ser a "divisão" da linguagem em três "tipos" de palavras.

Esta tríade aparece já na primeira linha do capítulo 27:28

$$
\begin{aligned}
& \text { 寓言十九, 重言十七, 后言日出, 和以天倪。 } \\
& \text { yùyán shí jiǔ, zhòngyán shí qū, zhīyán rì chū, hé y̌̌ tiānní. } \\
& \text { [Na linguagem] as palavras convidadas (yùyán 寓言) [compõem] } \\
& \text { nove décimos [dela]; as palavras repetidas ( chóngyán 重言) } \\
& \text { [compõem] sete décimos [dela]; as palavras-cálice (zhīyán 厄后) } \\
& \text { surgem dia [após dia], [tudo] harmonizando na Sutileza Celestial } \\
& \text { (tiānní 天倪). }
\end{aligned}
$$

$\mathrm{Na}$ análise da visão de linguagem inferida desse capítulo do Zhuāngž̆, interessa-nos, em particular, o contraste entre esses três termos metalinguísticos, nomeadamente, yùyán 寓言, chóngyán 重言 e zhīyán 厄言. Considera-se que os termos yù 寓, chóng 重e $z h \bar{l}$ 厄 modificam yán 言, que, por sua vez, é traduzido como língua, linguagem, palavra, dizer, falar, declaração, etc. Assim, trata-se de três "tipos" ou "qualidades" de linguagem (ou de palavras). A utilização obscura na passagem acima de "nove décimos" e "sete décimos" respectivamente para yùyán e chóngyán levou os intérpretes do texto a considerar que eles se referem a percentuais do número de palavras na língua (yùyán comporia $9 / 10$ - shí jiǔ 十九, "dez nove" - do total; chóngyán comporia 7/10 - shí qĩ 十七, "dez sete" - de 1/10 (o resto) ou poderia haver uma intercessão,

\footnotetext{
${ }^{28}$ Os trechos do capítulo são apresentados em caracteres chineses, seguidos da transcrição em pinnyinn (o padrão atual em uso na China continental) e de minha tradução para o português. Todos os caracteres chineses seguem o uso pré-reforma ortográfica na China continental de 1956/1964. A pontuação no texto chinês não existia no texto original e foi colocada posteriormente, seguindo a interpretação mostrada na tradução, com o objetivo de melhorar sua legibilidade. Na tradução para o português, inseri palavras não presentes no chinês entre colchetes e destaquei palavras-chave repetindo-as em pinnyin e em caracteres chineses. Dessa forma, acredito estar ajudando o leitor não conhecedor do chinês clássico a seguir mais facilmente minhas opções tradutórias. A transcrição em pinnyìn reflete a leitura atual dos caracteres e não aquela da época do Zhuāngzì.
} 
com palavras classificadas tanto como yùyán quanto chóngyán, como propõe Chen (2015, p. 837). Há outras interpretações e autores, como Wu (1988, p. 5), por exemplo, que consideram que os três termos serviriam à totalidade das palavras da língua, indicando suas características comuns e gerais. Independentemente da interpretação escolhida, é inegável que os três termos contribuam conjuntamente para a visão sobre as palavras e as representações da linguagem no Zhuāngž̌. Entre as três classes de palavras, entretanto, somente as zhìyán se harmonizam na "sutileza celestial" (tiānní 天倪). ${ }^{29}$

O texto prossegue então com uma exemplificação e explicação sobre o uso do primeiro termo, yùyán:

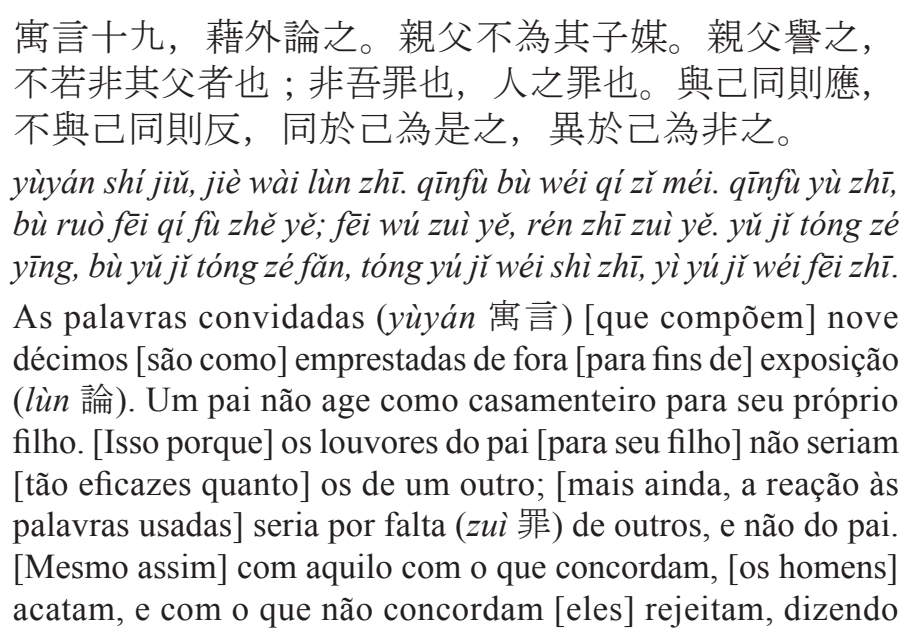

\footnotetext{
${ }^{29}$ Esse é um termo de difícil tradução. Mair (1994) usa: framework of nature (estrutura da natureza), Ziporyn (2009) traduz como Heavenly Transitions (transição celestial), Watson (2013) emprega Heavenly Equality (igualdade celestial), Wang (2004) a explica como a operação ou o balanceamento celeste. Enquanto tiān天 refere-se claramente ao "Céu" chinês, a abóbada celestial personificada pela figura do huángtiān 皇天, “imperador celestial", ní 倪 é um termo mais obscuro, em geral dicionarizado como diminuto, limite, fronteira, início. O comentarista GuōXiàng escreveu: 天倪者, 自然 之分也 tiānní zhě, zìrán zhī fên yě, "tiānní: a divisão/partição da natureza," parecendo referir-se às diminutas e fronteiriças divisões que ocorrem no mundo natural quando do surgimento do homem e da linguagem, rachaduras que pouco a pouco individualizam as coisas do mundo, separando-as umas das outras. Esse é o efeito produzido pela linguagem já referido também no capítulo 2 .
} 


$$
\begin{aligned}
& \text { “isso" ( } s h i \text { 是) para o que for igual (tóng 同) [ao que concordam] } \\
& \text { e “aquilo" ( fêi 非) para o que for diferente (yi 異). }
\end{aligned}
$$

No exemplo do texto, yùyán - que traduzi como "palavra convidada" - foi aquela palavra usada pelo casamenteiro para elogiar o candidato a noivo no lugar do pai, que, por ser pai, muito provavelmente teria sua opinião considerada como enviesada quando apresentasse seu próprio filho. Mais ainda, ao "emprestar" suas palavras ao casamenteiro, o pai transferiria a ele também a responsabilidade (“culpa", zui 罪) por elas.

Os tradutores e estudiosos do texto empregam uma grande diversidade de termos para traduzir yùyán, como vemos a seguir: Balfour (1881) e Mair (1994): metaphors (metáforas); Watson (2013): imputed words (palavras imputadas); Palmer (1996): supposed words (palavras supostas) e Billeter (1990): fable (fábula). Wang (2004) e $\mathrm{Wu}$ (1988) usam dwelling words (palavras que habitam), e Wu (1988, p. 5) escreve que "essas palavras 'habitam' na situação, de modo a nos guiar." Qiu (2005, p. 221) apresenta a lista "fable, allegory, parable" (fábula, alegoria, parábola), explicando que yùyán, no Zhuāngž̆, referese às palavras "faladas através da boca de personagens históricos ou ficcionais, de forma a torná-las mais convincentes." Kohn (2014), Wang (2014, p. 21) e Li (YU et al., 2000, p. 96) propõem os termos oportunos guest words (palavras convidadas) (Kohn) e lodged words (palavras hospedadas) (Wang e Li) que, em minha leitura, refletem explicitamente a grafo-etimologia do termo yù 寓 $^{30} \mathrm{em}$ seu deslocamento e uso em um diferente contexto, como comenta Kohn: "colocando a própria palavra na boca de outras pessoas." Na prática, esse efeito se dá em geral por meio

\footnotetext{
${ }^{30} \mathrm{O}$ caractere yù 寓 (que modifica yán 言) pode ser traduzido como residir, conter, ter residência, confiar ao cuidado de alguém, achar sustento em. Em sua definição no dicionário Shuōwén (séc. II d.C., a mais citada das referências lexicográficas do chinês antigo), o termo é glosado como

寓。寄也。从它聲

yù. jì yě. cóng mián yú shēng.

yù; como jì (pedir, confiar, depender, residir na casa de alguém), indicação semântica de mián (teto, casa), indicação fonética de yú.
}

Há, portanto, a alusão de um espaço que não é aquele original, mas onde se habita, provisoriamente, porque o inquilino inspira confiança. 
de figuras de linguagem, como expressões fixas, parábolas, descrições figurativas, conversas imaginárias ou diálogos fantasiosos.

Como vimos, no chinês clássico, certamente sob influência do próprio Zhuāngzǐ, yùyán foi usado para se referir a um estilo literário, normalmente de estórias curtas com uma moral (como aquelas que encontramos ao longo do próprio Zhuāngzī). Há assim a alusão a um termo que se refere ao uso "emprestado", às palavras que são retiradas de um contexto para ser usadas em outro (daí a tradução possível como metáfora). $\mathrm{O}$ fato de, no exemplo apresentado, a responsabilidade do pai ceder espaço àquela do casamenteiro (que "usou" as palavra do pai para elogiar o filho à procura de uma candidata ideal como noiva), nos mostra que as palavras emprestadas angariariam força (pragmática) dessa nova situação de uso. Ainda assim, essa estratégia parece não surtir efeitos relevantes, porque, como continua o texto, ao final, os interlocutores continuam a dizer "sim" somente para aquilo com que concordam e "não" para aquilo de que discordam.

O texto continua então com a explicação do segundo termo da tríade, zhòngyán ou chóngyán 重言:

重言十七，所以已言也，是為者艾。年先矣， 而無經緯本末以期年老者, 非先也。人而無以先人, 無人道也; 人而無人道, 是之謂陳人。

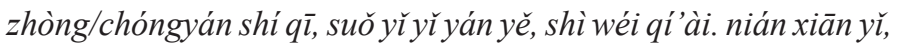
ér wú jīng wěi běn mò yĭ qĩ nián qí zhĕ, shì fêi xiān yě. rén ér wú yì xiān rén, wú rén dào yě; rén ér wú rén dào, shì zhī wèi chénrén. As palavras repetidas (chóngyán 重言) [que compõem] sete décimos destinam-se a parar a conversa (yán 言). Isso porque agem como [palavras dos] anciãos. [Se, no entanto, alguém está] à frente dos outros em idade, porém não compreende a complexidade da urdidura e do tecido, da raiz à copa, [tal como seria compatível] com seus anos, [então] não pode ser o primeiro [entre os homens]. Aquele que não é o primeiro [entre os homens] não [segue] o dào (道) do homem, e se não [segue] o dào do homem, é chamado de um "homem obsoleto" (chénrén 陳人).

O dígrafo 重言, transliterado em pīnyīn por chóngyán, é dicionarizado hoje como reduplicação. Já o caractere 重 isoladamente tem duas pronúncias-padrão no mandarim moderno: chóng ou zhòng. Como chóng, o caractere é traduzido presentemente como: repetir, 
repetitivo, novamente, implicar, camada, ao passo que na pronúncia zhòng traduz-se por: pesado, tornar-se pesado, sério, grosso, grave, solene, dificil, considerar importante (também para se referir a sensações: color profunda, som grave, etc.).

No Zhuāngzĭ, o dígrafo 重言 é lido como chóngyán pela maior parte dos tradutores. Mair (1994), Palmer (1996) e Ziporyn (2009) o traduzem como quotation ou citation (citação); Billeter (1990, p. 162) considera que se trata da "citação de uma autoridade;" Wang (2004, p. 196) o traduz por double-layered words (palavras com duas camadas); $\mathrm{Li} \mathrm{(YU} \mathrm{et} \mathrm{al.,} \mathrm{2000,} \mathrm{p.} \mathrm{96)} \mathrm{por} \mathrm{repeated} \mathrm{words} \mathrm{(palavras} \mathrm{repetidas);} \mathrm{Wu}$ (1988) emprega o poético opalescent words (palavras opalescentes), termo que remete ao jogo de brilhos de um raio que transpassa uma opala: as palavras são "'duplamente rajadas', ou seja, dizem algo a fim de obedecer a autoridade do que não dizem, sendo 'opalescentes' à luz da realidade" (WU, 1988, p. 5). Segundo Kohn (2014), chóngyán são as palavras duplas com múltiplas camadas, com realidades ambíguas, figurativas e imaginativas, correspondendo aproximadamente a uma “linguagem metafórica." Para Kohn, seu peso (lendo 重 como zhòng) "provavelmente transmite a autoridade advinda da experiência do orador" (KOHN, 2014, p. 171), e, dessa forma, também inclui aforismos e provérbios poéticos. De uma forma similar, Watson (2013), também aceita as duas leituras, chóng e zhòng, respectivamente como repeated words (palavras repetidas) e weighty words (palavras de peso). Finalmente Qiu (2005, p. 222) e Wang (2014, p. 22) são exceções ao priorizar a leitura de 重言 como zhòngyán, respectivamente traduzido como weighty words (palavras de peso) e grave words (palavras graves). Todavia esses autores também aludem à alternativa da leitura como chóngyán, "palavras dos sábios que são repetidamente citadas."

Vemos, portanto, que, com as notáveis exceções de Qiu e Wang, a maioria dos tradutores do Zhuāngzǐ opta por ler 重言 primariamente como chóngyán, enfatizando seu aspecto duplo. De fato, zhòngyán e chóngyán são geralmente tratados pelos sinólogos como um caso de duas palavras isoladas, com diferentes etimologias, cuja homonímia estaria restrita à sua forma gráfica. Entendo que, em concordância com Kohn, Watson, Qiu e Wang, as duas alusões acabam sendo relevantes 
para os efeitos desejados no texto e, na verdade, são complementares, coalescendo no dígrafo comum, 重言. ${ }^{31}$

O texto outorga às chóngyán o poder de "parar a conversa", ou seja, levar ao fim de uma discussão, o que claramente ressalta a autoridade dessas palavras, frequentemente empregadas como citações retiradas de texto canônicos antigos. Todavia, o Zhuāngž̌ nos adverte: o mero critério de antiguidade no uso das palavras dos antigos clássicos é inútil (e mesmo falacioso), caso essas palavras não estejam investidas de uma sabedoria e da compreensão do dào 道. Há, portanto, a crítica implícita contra o abuso de citações e a confiança cega em frases retiradas de textos antigos sem o acompanhamento de alguma leitura crítica ou a garantia de que elas teriam sido produto de um movimento em consonância com o dào 道. Essa posição está em perfeita harmonia com o cerne da crítica do Zhuāngzǐ contra os argumentos de Confucionistas e Moístas, correntes dominantes da tradição chinesa à época.

O último termo da tríade, aquele em geral considerado como o mais importante, zhīyán 厇言, ${ }^{32}$ e também uma expressão que foi pela primeira vez cunhada no Zhuāngž̆, tem uma breve explicação na continuação do texto:

$$
\begin{aligned}
& \text { 厄言日出, 和以天倪, 因以曼衍, 所以穿年。 } \\
& \text { 不言則齊，齊與言不齊，言與齊不齊也，故曰無言！ } \\
& \text { 言無言，終身言，未嘗言; 終身不言，未嘗不言。 } \\
& \text { zhīyán rì chū, hé y̌̌ tiānní, yīn y̌̀ màn yăn, suǒ yĭ qióng nián. bù } \\
& \text { yán zé qí, qi yǔ yán bù qí, yán yǔ qi bù qí yě, gù yuē wú yán! yán } \\
& \text { wú yán, zhōng shēn yán, wèi cháng yán; zhōng shēn bù yán, wèi }
\end{aligned}
$$

Com essas palavras-cálice (zhīyán 厄言) que surgem dia [após dia] ${ }^{33}$ tudo se harmoniza na Sutileza Celestial (tiānni ${ }^{\text {天倪), então }}$

\footnotetext{
${ }^{31}$ A guisa de simplicidade, a despeito dessa leitura explicitamente ambígua, doravante, ao me referir ao termo 重言, irei usar a transliteração preferida pela maioria dos sinólogos, chóngyán.

${ }^{32}$ A prioridade de zhīyán na tríade metalinguística do capítulo 27 - ver, por exemplo, Kohn (2015, p. 66) - não angaria, todavia, a unanimidade dos estudiosos do texto. Para uma visão alternativa, veja-se Cook (2003, p. 73).

${ }^{33}$ Ziporyn (2009, p. 114) faz uma interpretação completamente diferente desse início: "Estas palavras-cálice-transbordantes constantemente produzem [significados] [...]." Ao evitar o uso da palavra significado, minha tradução também segue as de Mair (1994),
} 
verte suas elaborações (màn 曼 $)^{34} \mathrm{e}$, assim, passam-se os anos. [Enquanto] nada for dito, permanece a uniformidade ( $q i$ 齊),$^{35}$ mas a uniformidade e o que se diz (yán 言) [sobre ela], já não mais perfazem a uniformidade; o que eu digo e a uniformidade já não mais perfazem a uniforme; por isso, digo: não-palavras (wú yán 無言)! Com palavras não-palavras (yán wú yán 言無言), falarás até o fim da vida, e nunca terás dito [nada]. [Ou] até o fim da vida não falarás, e nunca terá deixado de dizer [algo].

Zhīyán 后言, “inventado” por Zhuāngž̌, não é encontrado em mais nenhum outro texto pré-Qín que não comente o próprio Zhuāngž̆ (CHINESE TEXT PROJECT). O caractere que modifica "palavra" (yán 言), $z h i \bar{厄}$ 厄, é em geral hoje traduzido por cálice (goblet), frequentemente no dissílabo zhījiǔ 厄酒. A força da materialidade e concretude da referência leva a maior parte dos autores a usar essa tradução para o termo $z h \overline{1}$, na forma composta palavra-cálice. A exceção é dada por Mair (1994), que o traduz como impromptu words (palavras improvisadas), palavras usadas sem preparação prévia, repentinas e de improviso. Essas características destacadas por Mair, entretanto, também são aceitas, entretanto, por todos os comentaristas. Por exemplo, Wang (2014) escreve que as palavras-cálice são aquelas do "não-coração-mente, ${ }^{36}$ [são] não-

Palmer (1996), Watson (2013) e Chen (2015) e toda uma linha de pensamento que evita associar um termo metalinguístico tão central da tradição ocidental aos textos chineses (veja-se, por exemplo, essa discussão em Hansen (1985, 1992) ou Ames; Hall (1998). ${ }^{34}$ Wang (2004, p. 197) traduz esse trecho como "elas se acomodam às mudanças sem fim."

${ }^{35}$ qi 齊, um dos termos centrais no Zhuāngž̌, é hoje dicionarizado como regular, balanceado, em ordem, organizado, arrumado, concordar, igual, igualdade, comparável, similar(idade), com limite fixo. Ao traduzi-lo por uniformidade, procuro ressaltar seu contraste (aqui) com igualdade. Como vimos, o Zhuāngzǐ promove a defesa da igualdade, mesmo quando a uniformidade é quebrada (trocada pelo pluralismo) com a instituição da linguagem. Veja-se uma discussão sobre qi em Wang (2014, p. 190-191). ${ }^{36} \mathrm{O}$ termo chinês $x \bar{n}$ 心 é aqui traduzido como "coração-mente," em uma interpretação quase que trivial: pictograficamente o caractere representa o coração e, como na tradição chinesa o coração é o centro dos sentimentos e pensamentos, aproximamos funcionalmente o termo para o conceito ocidental de "mente." É importante, todavia, destacar que a dicotomia ocidental emoção/razão acaba se dissolvendo e confluindo neste "único" órgão humano, xīn 心. 
palavras, então, como a linguagem de crianças mais jovens, que não devem ser julgadas ou avaliadas" (WANG, 2014, p. 24).

A quase totalidade dos intérpretes do texto apoia-se na leitura que se consagrou na tradição exegética chinesa e que exemplifico nas palavras de Watson (2013, p. 234):

"palavras cálice", [são] palavras que são como uma taça que se inclina quando cheia e endireita-se naturalmente quando vazia, isto é, que se adapta e segue junto com a natureza flutuante do mundo e, assim, alcança um estado de harmonia. ${ }^{37}$

Trata-se, portanto, de um cálice bojudo (como uma taça para conhaque) sem pé, cujo formato em "U" o mantém em permanente estado de precário equilíbrio. Quando preenchido com algum líquido, esse equilíbrio é afetado e provoca um aumento da instabilidade, até o ponto em que o cálice finalmente tomba para o lado, deixando escorrer seu conteúdo e posteriormente voltando à sua posição inicial, novamente vazio. O caráter fluido de zhȳyán levou Palmer (1996) a usar a tradução de flowing words (palavras fluidas) que remete à sua falta de estabilidade e à fácil perda de equilíbrio do cálice. ${ }^{38}$

${ }^{37}$ Para algumas referências aos comentaristas chineses no original em chinês, veja-se Chen (2015, p. 837).

${ }^{38}$ Ao escorrer, seu "conteúdo" é descartado, ação que se reflete a uma importante passagem do capítulo 26 do Zhuāngzĭ:

荃者所以在魚, 得魚而忘荃; 蹄者所以在兔, 得兔而忘蹄; 言者所以在意, 得意而忘言。吾安得忘言之人而與之言哉?

quán zhě suǒ yľ zài yú, dé yú ér wàng quán; tí zhě suǒ yľ zài tù, dé tù ér wàng tí; yán zhě suǒ y̌̌ zài yì, dé yì ér wàng yán. wú ān dé wàng yán zhī rén ér yŭ zhī yán zāi?

Armadilhas para peixes [são] usadas para peixes; [uma vez] obtido um peixe, esquecem-se as armadilhas. Laços para coelhos [são] usados para coelhos; [uma vez] obtido o coelho, esquecem-se os laços. Palavras [são] usadas para $y i$ 意; uma vez obtido $y i$ 意, esquecem-se as palavras. Eu onde [poderia] obter um homem que esqueceu (wàng 忘) as palavras, e [com ele] trocar palavras?

Nessa passagem, podemos fazer um paralelo com as palavras-cálice do capítulo 27, substituindo-se o "líquido" do cálice-sem-pé por yì 意. Uma vez que o líquido escorreu do cálice, esquecemos a forma como havíamos usado aquela instância de zhìyán, escapa-nos aquele momento de naturalidade e improviso. Nessa passagem do 
Assim que introduzimos a linguagem - e aqui zhīyán é metonímia para o uso mais irrestrito e geral para linguagem, tal como apreendida pelo Zhuāngž - a uniformidade primordial (o "caos", o "todo difuso", hùndùn 混沌) começa a mostrar suas distinções e separações: uma vez que há linguagem, não é possível que haja agora somente unidade. Esse resultado é ao mesmo tempo desejado - afinal, é consequência natural do surgimento do ser humano - e temido, por ser o momento quando surgem as distinções, as hierarquias, as doutrinas e o "conhecimento teórico" (advindo do discurso, lùn 論); em outras palavras, o risco de que a falta de uniformidade seja confundida com a desigualdade. Por isso o partidarismo do Zhuāngzı̌ pelas "palavras não-palavras", aquelas que quebram a uniformidade sem que sejam impostas categorias e hierarquias. As "palavras não-palavras" seriam idealmente representadas por zhìyán.

Qiu (2005, p. 222) escreve que zhìyán são aquelas palavras que "se adaptam à natureza mutante do mundo e, dessa forma, estão em harmonia com o Dao." Elas seriam, nessa leitura, a ponte que uniria os capítulos 1 e 2 do Zhuāngž̆, o reflexo da natureza (zìrán 自然) na linguagem - aqui compreendida como toda e qualquer atividade humana, como cultura

capítulo 26, as palavras servem para capturar ou obter (dé 得) yì e, uma vez obtido este $y i ̀$, descartamos seu receptáculo. Propositalmente optei por manter o termo original yì na tradução acima, uma vez que ele é usualmente traduzido como significado ou intenção, dois termos que carregam uma complexa gama de alusões e referências na tradição ocidental, que poderiam ser questionados no âmbito de um texto da época dos Zhôu orientais (ver notas 24 e 27).

A passagem do capítulo 26 torna ainda mais complexa a questão ao terminar com uma situação paradoxal e claramente irônica: onde encontraríamos alguém que se esqueceu das palavras para que pudéssemos trocar algumas palavras com ele/a? Essa frase tem duas interpretações cabíveis no âmbito do Zhuāngž̌. A primeira parece mais óbvia: ao contrário de armadilhas para peixes e coelhos, as palavras não são descartáveis, elas permanecem relevantes, mesmo após serem "entendidas." Essa interpretação é compatível com a importância das palavras-cálice no capítulo 27, pois, caso fossem meramente descartadas, não tomariam um papel central na manutenção da harmonia na "Sutileza Celestial." A segunda interpretação é mais sutil: o Zhuāngž̌ prega que o conhecimento último (a "iluminação", míng 明) só seria atingido por meio do esquecimento (wàng 忘) das palavras, ou seja, do não apego a seus usos anteriores. São esses usos (os “ $y i$ 意” anteriores) que devem ser descartados e esquecidos. Dessa forma, ao procurarmos os sábios ("homens verdadeiros", zhēnrén 真人) para aprendermos sobre dào 道 com eles, estamos procurando aqueles que conseguiram "esquecer as palavras." (Sobre 忘 wàng, esquecer, veja-se Cheng (2005, p. 161-168)). 
no sentido mais amplo. Zhīyán ofereceria assim a possibilidade do agir sem ação, de seguir dào 道 em consonância com a harmonia natural e os ritmos da inconstância da natureza. A importância de zhīyán em contraste com yùyán e chóngyán está clara na leitura de Wang (2004) que vê nestas duas últimas os aspectos concretos da linguagem e na primeira "a postura geral do Zhuāngž̌ em relação ao seu uso da linguagem" e "o aspecto mais filosófico da teoria do linguagem e da autoexpressão [no Zhuāngzi]" (WANG, 2004, p. 196).

No último trecho que comentaremos no presente artigo, o texto prossegue oferecendo uma explicação adicional sobre zhīyán e assim ressalta sua importância:

有自也而可，有自也而不可; 有自也而然，有自也而 不然。惡乎然? 然於然。惡乎不然? 不然於不然。 惡乎可? 可於可。惡乎不可? 不可於不可。 物固有所然，物固有所可，無物不然，無物不可。 非后言日出, 和以天倪, 孰得其久! 萬物皆種也, 以不同形相禪，始卒若環，莫得其倫，是謂天均。 天均者，天倪也。

yǒu zì yě ér kě, yǒu zì yě ér bù kě; yǒu zì yě ér rán, yǒu zì yě ér bù rán. è hū rán? rán yú rán. è hū bù rán? bù rán yú bù rán. è hü kě? ké yú kě. è hü bù kě? bù kě yú bù kě. wù gù yǒu suó rán, wù gù yǒn suǒ kè, wú wù bù rán, wú wù bù kè. fêi zhìyán rì chū, hé yĭ tiān ní, shú dé qí jiǔ! wànwù jiē zhǒng yě, yì bù tóng xíng xiāng chán, shĭ zú ruò huán, mò dé qí lún, shì wèi tiānjūn. tiānjūn zhè, tiānní yě.

Há isso [que torna as coisas] aceitáveis ( $k e ̌$ 可); há isso [que torna as coisas] não aceitáveis (bù kě 不可); há isso [que faz as coisas] assim (rán 然); há isso [que faz as coisas] não assim (bù rán 不然). O que as faz assim? [Considerá-las] assim as torna assim. O que as faz não assim? [Considerá-las] não assim as torna não assim. O que as torna aceitáveis? [Considerá-las] aceitáveis as torna aceitáveis. O que as torna não aceitáveis? [Considerá-las] não aceitáveis as torna não aceitáveis. As coisas (wù 物) certamente têm o que é assim; as coisas certamente têm o que é aceitável. Não há o que não seja assim; o que não seja aceitável. Sem as palavrascálice (zhīyán 后言), surgindo dia [após dia] para tudo harmonizar na Sutileza Celestial (tiānní 天倪), quem [sobreviveria] por longo tempo! As dez mil coisas (wànwù 萬物) provêm de sementes, e suas diferentes formas dão lugar uma a outra. Começar e terminar 
são como um anel, e não se pode obter o arranjo correto [das coisas] (lún 倫). Isso se chama de Igualdade Celestial (tiānjūn 天均). ${ }^{39}$ Igualdade Celestial, a Sutileza Celestial.

Esse trecho reforça o aspecto iconoclasta e transgressor do Zhuāngž̆, de rompimento das barreiras e das discriminações. Com sua tradução é inevitável percebermos o viés fortemente relativista de suas palavras ("as coisas são como as chamamos", "não há o que não seja aceitável"). Interessa-nos aqui a posição central das palavras-cálice: não somente como fonte das diferenças (portanto, do "relativismo"), mas também como elemento responsável por seu equilíbrio e harmonia, na medida em que impede que essas diferenças coalesçam como hierarquias e desigualdades. A passagem termina com um trecho que, a despeito de seu pendor nitidamente místico, pode também ser lida de uma maneira mais direta: em um mundo em eterna mutação, em que as palavras estão constantemente se renovando, é impossível reconhecer início e fim, e seria utópico uma compreensão completa de todas as relações. Reconhecer essas limitações é um dos objetivos do Zhuāngž̌, a aceitação do princípio de igualdade na ausência de uniformidade ou constância.

Para Hoffman o modo de falar do Zhuāngž̆, que é tão elusivo e difícil - particularmente quando o texto discorre sobre a própria linguagem - é como

querer falar e ao mesmo tempo querer esquecer as palavras [...] uma maneira de falar que não é mais útil e já não mais pode ser usada como um argumento em debates, como um instrumento de discernimento [... mas] que, ao mesmo tempo insiste na importância e na eficácia de suas ideias. Esse modo de falar é falar em 'palavras cálice' [...] saídas do céu, saídas da água. (AMES; NAKAJIMA, 2015, p. 43)

${ }^{39}$ A "Igualdade Celestial" é traduzida por muitos autores como "Roda Celestial do Oleiro." Ziporyn (2009, p. 14) explica como a imagem da roda do oleiro é uma metáfora comum na tradição chinesa para uma abóboda celestial em rotação, equalizando as coisas à medida que, devido à sua rotação, o barro se distribui homogeneamente sobre sua superfície. Ao mesmo tempo, o Zhuāngzǐ também emprega a ideia da roda em movimento, chamando a atenção para a mutação constante das perspectivas (veja-se Zhuāngzǐ, cap. 2). 
$\mathrm{Na}$ tríade metalinguística que nos sugere o capítulo 27, os trechos do Zhuāngž̌ aqui traduzidos resumem de maneira brilhante as características da linguagem zhuangziana: a liberdade e precariedade como as palavras são convidadas a ser utilizadas em diversos contextos (palavras convidadas, yùyán 寓言); o peso da sua autoridade quando, inúmeras vezes citadas e repetidas, sua liberdade é ameaçada quando se veem engessadas nos textos dos antigos sábios (palavras repetidas, chóngyán 重言); e, finalmente, a superação dessa dicotomia liberdade/ prisão no reconhecimento de sua renovação suprema como geradoras incansáveis de atos linguísticos perfeitamente inefáveis, improvisados e fugazes (palavras-cálice, zhìyán 厄言).

\section{Conclusões}

Embora superficialmente não aparente ser um texto que trate diretamente da linguagem, o Zhuāngž é uma peça literária que emprega magistralmente a própria linguagem na exploração de seus limites e potenciais, sendo considerado por muitos um dos textos mais ricos linguisticamente no cânone clássico chinês. Kohn (2014,p. 170) escreve que as palavras do Zhuāngž̌ são extravagantes, cheias de expressões irregulares e paradoxais, irresponsáveis e ininteligíveis. Alguns termos exóticos (concentrados nos capítulos 2 e 33) ilustram sua metalinguagem extremamente imaginativa: diàogǔ̌ 詭, [palavras que levam à] enganação suprema (cap. 2); wàngyán 妄言, palavras amalucadas (cap. 2); mènglàng 孟浪, [palavras] impetuosas e impulsivas (cap. 2); kuángyán 狂言, palavras selvagens (cap. 22); miùyōuzhīshuō 謬悠之說, termos estranhos e extravagantes (cap. 33); huāngtángzhīyán 荒唐之言, palavras impetuosas e bombásticas (cap. 33); e wúduānyázhīcí 無端崖之辭, frases sem restrições ou fronteiras (cap. 33). Os termos empregados nos levam a pensar em um uso linguístico improvisado, sem conhecimento de causa, imediato, inconsequente, perigoso $(\mathrm{KOHN}$, 2014, p. 171); são as "loucas palavras" (crazy words) do Zhuāngž̌ e sua "forma de usar a linguagem ao mesmo tempo que demonstra sua compulsão em demoli-la" (WANG, 2014, p. 25). Impossível não nos impressionarmos diante da afinidade com as palavras de Wittgenstein: "É preciso não esquecer que o jogo da linguagem é dizer o imprevisível - isto é: não se baseia em fundamentos, não é razoável (ou irrazoável), está aí com a nossa vida" (WITTGENSTEIN, 1998, Da Certeza, §559). 
Nessa defesa de uma linguagem pragmática não fundada sobre uma base racional, mas voltada para a primazia do uso linguístico, proponho aqui restituir ao capítulo 27 do Zhuāngž̌ a ocupação de um lugar de maior proeminência na HIL chinesa do que lhe é comumente outorgado.

O que no capítulo 2 surge como a exaltação da força de uma linguagem livre e criativa está explorado de uma forma mais sistemática - um termo que certamente o(s) autor(es) do Zhuāngzǐ repudiaria(m)! - e explícita no início do capítulo 27. É quase inevitável reconhecer que, na tríade metalinguística desse capítulo, zhīyán assuma um papel de destaque. É o único termo que foi cunhado pelo Zhuāngž̌ e aquele cujo uso posterior tornou-se sempre intimamente ligado a esse momento inaugural. Alguns autores como Li (YU et al., 2000) chegam mesmo a considerar que os outros dois termos seriam apenas subcategorias de zhìyán, meras ênfases em seu leque de referências. Entretanto, como já vimos neste artigo, defendo que os três termos tenham contribuições complementares e fundamentais à linguagem zhuangziana.

Sugiro aqui que o início do capítulo 27, traduzido e comentado para este artigo, indique uma hierarquização precária, um movimento que espelhe o debate na filosofia chinesa de sua época: a quase totalidade $(9 / 10)$ da linguagem que usamos é formada por palavras que lemos ou ouvimos, retiramos de algum contexto para utilizar em outro, são as yùyán 寓言. Nessa etapa, adverte-nos o Zhuāngzǐ, há um esforço retórico e uma tentativa de se estabilizar a relação palavra/coisa que, entretanto, está fadado ao fracasso: aqueles que, desde antes, aceitam e concordam com o que dizemos, respondem positivamente ( $s h i$ 是), já os que nunca aceitaram continuam em sua recusa ( $f \bar{e} i$ 非). Diante do fracasso das yùyán, autores, como Confúcio, Mòzǐ e outros, apelaram à autoridade dos clássicos canônicos, às palavras do reis-sábios, às citações das palavras de peso, chóngyán 重言, estas, sim, capazes de levar uma discussão a seu cabo. Entretanto, avalia o Zhuāngž̆, essa autoridade por si só não é garantia de palavras em conformidade com dào 道, e,frequentemente, citações são feitas sem rigor ou critério, convertendo-se em meras repetições que preenchem o discurso, mas não dizem nada. Correm o risco de tornar-se - referindo-se ao capítulo 2 - apenas o "sopro do vento" (chū 吹). Porém - como lemos neste trecho do próprio capítulo 2: 夫言非吹 也 fū yán fềi chuī yě, "palavras não são o sopro do vento" - o Zhuāngž̌ recusa uma visão tão negativa sobre a linguagem. O que se defende aqui 
é que a diferença entre a linguagem e o sopro do vento encontra-se na capacidade perene da linguagem de mudar e de se renovar, esvaziar-se, sem que se torne vácua ou estéril. E essa é a capacidade representada por zhīyán 厄言, locus da contradição da pseudo-vacuidade que é a linguagem humana.

Neste momento, reforço o que foi proposto no início deste artigo, chamando novamente a atenção para o notável paralelo do Zhuāngž̆ com o pensamento de Wittgenstein, Harris e Taylor: o elogio ao poder da linguagem, em sua propensão a usos inesperados, não calculados, porém sempre exigindo vigilância contra o espectro da armadilha da reificação. Argumento que zhīyán represente uma espécie de contraparte zhuangziana à linguagem ordinária e comum de Wittgenstein, aquela que se renova a cada uso, que recusa o cálculo, que se sustenta sobre as bases frágeis e incertas do momento. Acredito que não só esse paralelo deva ser mais bem explorado na sinologia e na HIL, como também deva ser restituída a posição fundamental do Zhuāngzǐ não somente como um autor/livro iconoclasta e arguto crítico das linhas ortodoxas de pensamento na China Zhōu, mas também como fonte de uma singular interpretação sobre a linguagem.

Ainda segundo o Zhuāngž̌, a linguagem e o humano impõe à Natureza o inevitável esfacelar da unidade primordial. Ao romper com a unidade, também se rompe a uniformidade, porém, na pluralidade perspectivista do Zhuāngž̀ (ZIPORYN, 2009b), o perigo está representado pelo risco da criação de categorias estanques, divisões engessadas, hierarquias congeladas. Trazendo novamente o auxílio das palavras de Wittgenstein, podemos conceber que seja um risco similar àquele representado pelo uso das palavras "de férias", ou seja, fora de seus contextos de uso (WITTGENSTEIN, 2009, §38). A dificuldade de lidar com uma linguagem que incite a pluralidade e ao mesmo tempo tenda à classificação e à quebra da igualdade é o que levaria o próprio Zhuāngž̆ a se refugiar em suas "palavras sem palavras" (言無言 yán wú yán). Todavia, a solução proposta no texto, como sugiro aqui, encontra-se no bojo da própria linguagem, representada pelas zhīyán 厄言, que afastam o quietismo e promovem a criatividade máxima do ato linguístico.

Seria um equívoco, portanto, interpretar a hierarquização tripartite do capítulo 27 como proposta de uma sistematização estanque e ontologizante da linguagem. Ao outorgar às zhīyán a posição mais alta nessa hierarquia, o texto joga por terra qualquer tentativa de manter a 
própria hierarquia: o cálice, cheio, inclina-se e deixa, assim, escapar o que havia dentro dele...

No último capítulo do Zhuāngzĭ (capítulo 33, tiān xià 天下, Sob $o$ Céu), a tríade metalinguística introduzida no capítulo 27 é novamente retomada. Segundo o texto, em certa ocasião, Zhuāng Zhōu ouve falar de um dào 道 que promove uma igualdade que é vazia, infinita, nunca constante, e assim se maravilha com ele. ${ }^{40} \mathrm{O}$ texto descreve então a reação de Zhuāng Zhōu:

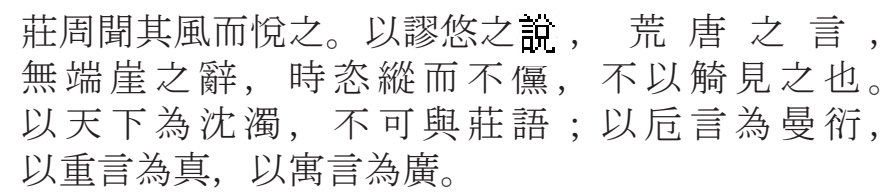

Zhuāngzhōu wén qí fêng ér yuè zhī. y̌̀ miù yōu zhī shuō, huāng táng zhī yán, wú duān yá zhī cí, shí zī zòng ér bù tăng, bù yì yuàn jiàn zhī yě. y̌̌ tiānxià wéi shěn zhuó, bù kě yǔ zhuāng yǔ; y̌̌z zhìyán wéi màn yăn, yǔ chóngyán wéi zhēn, y̌̀ yùyán wéi guăng.

Zhuāng Zhōu ouviu [as] palavras ao vento (fēng 風) e encantouse. [Ele as] expôs em termos estranhos e extravagantes (miù yōu zhī shuō 謬悠之說), em linguagem impetuosa e bombástica (huāng táng 荒唐), em frases sem restrições e sem fronteiras, abandonando-se aos tempos despreocupados, e não usando um olhar excludente. [Considerou] o sob-o-céu (tiānxià 天下) afogado em turvação (shěn zhuó 沈濁), impossível [de abordar] com uma linguagem sóbria (zhuāng yǔ 莊語). [Então ele] usou palavras-cálice (zhīyán 厄言) para verter suas elaborações (mànyăn 衍曼), palavras repetidas (chóngyán 重言) para dar autenticidade (zhên 真) $)^{41}$ e palavras convidadas (yùyán 寓言) para conferir grande amplitude (guăng 廣).

\footnotetext{
${ }^{40}$ Podemos especular que este trecho oferece uma representação mítica do momento em que próprio Zhuāngzǐ lê o Lăož̀.

${ }^{41}$ Diversos autores traduzem zhēn 真 como verdade. Há uma feroz disputa indefinida sobre a validade de um conceito de verdade no pensamento chinês clássico e seus detalhes ultrapassam em muito o âmbito e o tema do presente artigo. Kohn (2014, p. 170) escreveu: "Não há um conceito fixo - ou mesmo uma única palavra - para a 'verdade' palpável e permanente no sentido ocidental, apenas vários termos e perspectivas em constante mudança." Para a posição de que "não há conceito de verdade na filosofia chinesa", veja-se Hansen $(1985,1992)$ ou Owen (1992); para uma crítica, veja-se Lenk (1993, cap. 4).
} 
É notável que, ao se referir ao tipo de linguagem que falhe na vã tentativa de descrever o mundo em toda a sua mudança e complexidade - a chamada "linguagem sóbria" - o texto use o termo zhuāng 莊, o mesmo que dá nome ao seu autor, Zhuāngž̆ 莊子, “mestre Zhuāng”! Há uma ironia marcante que, mais uma vez, põe em evidência a contradição inerente da linguagem zhuangziana, por um lado iluminada em consonância com dào 道, e, por outro, resistente às amarras, sem se deixar domesticar. Como vimos nas passagens aqui analisadas, e, em particular, no capítulo 27 , a linguagem carrega seu poder imenso lado a lado com um terrível perigo. Porém, em vez de procurar colocá-la em uma camisa de força, o Zhuāngž̆, sem recuar para o conforto da linguagem sóbria, zhuāng yǔ, propõe abraçar sua completa liberdade, jorrando as mais amplas e autênticas elaborações por meio de suas zhīyán.

\section{Agradecimentos}

O presente trabalho é fruto de pesquisa de pós-doutorado na Universidade Federal Fluminense - UFF, realizada com apoio do CNPq, Conselho Nacional de Desenvolvimento Científico e Tecnológico - Brasil (152017/2016-0). Agradeço a inestimável ajuda da minha supervisora na UFF, Profa. Dra. Vanise Gomes de Medeiros.

\section{Referências}

ALLETON, Viviane. L'écriture chinoise: le défi de la modernité. Paris: Éditions Albin Michel, 2008.

ALLINSON, Robert E. Chuang-Tzu for Spiritual Transformation: An Analysis of the Inner Chapters. Albany: State University of New York Press, 1989.

AMES, Roger; HALL, David. Thinking from the Han. Albany: State University of New York Press, 1998.

AMES, Roger; NAKAJIMA, Takahiro (Org.). Zhuangzi and the Happy Fish. Honolulu: University of Hawai'i Press, 2015.

AUROUX, Sylvain. Histoire des Idées Linguistiques (tome 1, 2 and 3). Liège: Pierre Mardaga Editeur, 1995, 1992 e 2000.

AUROUX, Sylvain. A revolução tecnológica da gramatização. Tradução de Eni Puccinelli Orlandi. Campinas: Ed. Unicamp, [1992] 2009. 
AUROUX, Sylvain. La Philosophie du langage. Paris: Ed. Presses Universitaires de France, 2004.

BALFOUR, Frederic Henry. The Divine Classic of Nanhua, Being the Works of Chuang Tsze, Taoist Philosopher. Shanghai and Hong Kong: Kelly and Walsh, 1881. Disponível em: <http://ebook.lib.hku.hk/ CADAL/B31418934/>. Acesso em: 18 jul. 2017.

BAO, Zhiming. Language and World View in Ancient China. Philosophy East and West, Honolulu, v. 40, n. 2, p. 195-219, 1990.

BARROS BARRETO, Cristiano M. Pensares sobre a escrita chinesa. 2011. 213f. Dissertação (Mestrado) - Pontifícia Universidade Católica, Rio de Janeiro, 2011.

BARROS BARRETO, Cristiano M. Translation and metalanguage in Laozi: a perspectivist approach. 2015. 2 v.; 425f. Tese (Doutorado)Pontifícia Universidade Católica, Rio de Janeiro, 2015.

BILLETER, François. Zhuangzi poète ou philosophe. Études Chinoises, v. IX, n. 2, p. 161-170, 1990.

BOTTÉRO, Françoise; HARBSMEIER, Christoph. The Shuowen Jiezi Dictionary and the Human Sciences in China. Asia Major, Taiwan, third series, v. 21, n. 1, p. 249-271, 2008.

BOTTÉRO, Françoise. Chinese writing: ancient autochthonous perspective. Mémoire d'Habilitation à diriger des recherches sous la direction d'Alain Peyraube, 2011.

CAVELL, Stanley. The Claim of Reason. Oxford: Oxford University Press, 1979.

CHAN, Wing-Tsit. A Sourcebook in Chinese Philosophy. New Jersey: Princeton University Press, 1963.

CHEN Guying 陈鼓应. Zhuangzi jin zhu jin yi 庄子今注今译 (Notas e tradução moderna do Zhuangzi). 北京: 商务印书馆. Beijing: Shangwuyin Shuguan, [1995] 2015. 2 v.

CHENG, Anne (Org.). Y a-t-il une philosophie chinoise? Extrême-Orient, Extrême-Occident: Cahiers de Recherches Comparatives. Saint-Denis: Presses Universitaires de Vincennes, 2005. n. 29. 
CHINESE TEXT PROJECT. Disponível em: <http://ctext.org/>. Acesso em: 2 ago. 2017.

COOK, Scott. Hiding the World in the World: Uneven Discourses on the Zhuangzi. Albany: State University of New York Press, 2003.

CUA, Antonio (Ed.). Encyclopedia of Chinese Philosophy. Londres: Routledge, 2003.

ELMAN, Benjamin. From Value to Fact: The Emergence of Phonology as a Precise Discipline in Late Imperial China. Journal of the American Oriental Society, American Oriental Society, v. 102, n. 3, p. 493-500, 1982.

FERREIRA, Eduardo Pereira. Chuang Tzu: ensinamentos essenciais. Tradução de Sam Hamill e J. P. Seaton. São Paulo: Cultrix, 2005. [The Essential Chuang Tzu. Boston; London: Shamballa, 1999].

FUNG Yu-lan; BODDE, Derk. A History of Chinese Philosophy, Princeton: Princeton University Press, 1983. v. 1 e 2.

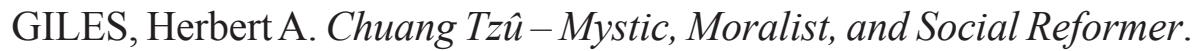
London: Bernard Quaritch, 1889.

GLOCK, Hans-Johann. A Wittgenstein Dictionary. Oxford: WileyBlackwell, 1996.

GRAHAM, A.C. Chuang-tzu's Essay on Seeing Things as Equal. History of Religions, Chicago, v. 9, n. 2/3, p. 137-159, 1969.

GRAHAM, A. C. Chuang-tzu: the Inner Chapters. London: George Allen \& Unwin Paperbacks, 1981.

GRAHAM, A.C. Disputers of the Tao: Philosophical Arguments in Ancient China. Chicago: Open Court Publishing Company, 1989.

GU HANYU DA CIDIAN (古汉语大辞典) (Grande Dicionário do Chinês Arcaico) (versão para iOS, 2001-2017. Pleco Inc, original editado por: 上海辞书 出版社 Shanghai cishu chubanshe). Shanghai.

HANSEN, Chad. Chinese Language, Chinese Philosophy, and "Truth." Journal of Asian Studies, Cambridage, v. XLIV, n. 3, p. 491-519, 1985.

HANSEN, Chad. A Daoist theory of Chinese thought. Oxford: Oxford University Press, 1992. 
HARRIS, Roy. The Language Myth. London: Duckworth, 1981.

HARRIS, Roy. Language, Saussure and Wittgenstein: How to play games with words. London: Routledge, 1988.

HARRIS, Roy. Rethinking Writing. London; New York: Continuum Press, 2001.

KJELLBERG, Paul; IVANHOE, Philip. Essays on Skepticism, Relativism and Ethics in the Zhuangzi. New York: State University of New York Press, 1996.

KNECHTGES, David; CHANG, Taiping. Ancient and Early Medieval Chinese Literature: a reference guide. Leiden: Brill, 2014. v. IIII.

KOHN, Livia. Zhuangzi: Text and Context. St. Petersburg: Three Pines Press, 2014.

KOHN, Livia (Ed.). New Visions of the Zhuangzi. St. Petersburg: Three Pines Press, 2015.

KOHN, Livia; ROTH, Harold D. (Ed.). Daoist identity: history, lineage, and ritual. Honolulu: University of Hawai'i Press, 2002.

LAI, Karyn L. Introdução à Filosofia Chinesa. Tradução de Saulo Alencastre. São Paulo: Ed. Madras, 2009. [An Introduction to Chinese Philosophy. Cambridge: Cambridge University Press, 2008]

LENK, Hans; PAUL, Gregor (Ed.). Epistemological Issues in Classical Chinese Philosophy. Albany: State Univesity of New York Press, 1993.

LEPSCHY, Giulio. (Ed.). History of Linguistics: the eastern traditions of linguistics. New York: Longman Publishing, 1994. v. 1.

LIN, JeeLoo. An Introduction to Chinese Philosophy: from ancient philosophy to Chinese Buddhism. Malden: Blackwell Publishing, 2006.

LIU Xiaogan (Ed.). Dao Companion to Chinese Philosophy. Berlin: Springer Verlag, 2015.

MAIR, Victor. Wandering on the Way: early taoist tales and parables of Chuang Tzu. New York: Bantam Books, 1994.

MAIR, Victor. Experimental Essays on Chuang-tzu. Honolulu: University of Hawai'i Press, 1983. 
O’NEILL, Timothy Michael. Ideography and Chinese Language Theory: a History. Berlin: De Gruyter, 2016.

OWEN, Stephen. Readings in Chinese Literary Thought. Council on Asian Studies. Cambridge: Harvard, 1992.

PALMER, Martin. The Book of Chuang Tzu. London: Penguin Classics, 1996.

Peipei QIU. Bashô and the Dao: The Zhuangzi and the Transformation of Haikai. Honolulu: University of Hawaii Press, 2005.

SOUZA, Julia Garcia Vilaça de. Zhuangzi: uma tradução comentada do segundo capítulo (versão corrigida). 2016. 115 f. Dissertação (Mestrado) - Faculdade de Filosofia, Letras e Ciências Humanas, USP, São Paulo, 2016.

TAYLOR, Talbot. Theorizing Language. Bingley: Emerald Press, 1997.

TAYLOR, Talbot. Language constructing language: the implications of reflexivity for linguistic theory. Language Sciences, Elsevier, n. 22 p. 483-499, 2000.

TOLEDO, Yolanda Steidel. CHUANG TZU: Escritos Básicos. São Paulo: Cultrix, 1995. [Tradução de WATSON, Burton. Zhuangzi: basic writings. Columbia University Press, 2003]

WANG Bo. Zhuangzi: thinking through the inner chapters. St. Petersburg: Three Pine Press, 2014.

WANG Li王力 Zhongguo Yuyan Xueshi (História da Linguística Chinesa) 中国 语言学史. 上海：复旦大学出版社 (Shanghai: Fudan Daxue Chubanshe), Shanghai, 2005.

WANG, William S.-Y.; Chaofen SUN. The Oxford Handbook of Chinese Linguistics. Oxford: Oxford University Press, 2015.

WANG, Youru. The strategies of 'goblet words': indirect communication in the Zhuangzi. Journal of Chinese Philosophy, Wiley Online Library, n. 31, n. 2 p. 195-218, 2004.

WATSON, Burton. The Complete Works of Chuang Tzu. New York: Columbia University Press, [1968] 2013. 
WIEGER, Léon. Nan-hoa-tchenn-king: l'oeuvre de Tschoang-tzeu in: Taoisme, 1913. v. 2.

WITTGENSTEIN, Ludwig. Philosophische Untersuchung Philosophical Investigations. Translated by G. E. M. Anscombe, P. M. S. Hacker and Joachin Schulte. Malden: Wiley-Blackwell, 2009.

WITTGENSTEIN, Ludwig. The Collected Works of Wittgenstein. Edited by G. H. von Wright and G. E. M. Anscombe. Malden: Blackwell, 1998.

WU, Kuang-ming. Goblet Words, dwelling words, opalescent words - philosophical methodology of Chuang-tzu. Journal of Chinese Philosophy, Wiley Online Library, n. 15, p. 1-8, 1988.

XU, Shen (Han) 許慎（漢）/ Xu Xuan (Song) 徐鉉（宋）Shuowen Jiezi 說文解字. 上海: 上海古籍出版社 (Shanghai, Shanghai Guji Chubanshe). Shanghai, 2004.

YU, Pauline; BOL, Peter; OWEN, Stephen; PETERSON, Willard. Ways with words. Berkeley: University of California Press, 2000.

ZIPORYN, Brook. Zhuangzi: The Essential Writings: With Selections from Traditional Commentaries. Indianapolis: Hackett Publishing Company, 2009.

ZIPORYN, Brook. Zhuangzi as a Philosopher. (Anexo online ao livro Zhuangzi: The Essential Writings, 2009b. Disponível em: $<$ https://www. hackettpublishing.com/ zhuangzisup>. Acesso em: 2 ago. 2017. 
